\title{
USUCAPIÃO E O DIREITO AGRÁRIO: uma visão geral da aplicabilidade da usucapião no direito agrário e a usucapião especial rural
}

Wagner Saraiva Ferreira Lemgruber BOECHAT ${ }^{*}$

\begin{abstract}
*Advogado, consultor Ambiental, professor de Direito na Universidade Vale do Rio Verde e Faculdade de São Lourenço. Graduado em Direito pela Faculdade de São Lourenço, pós-graduado em Direito Público pela Faculdade de São Lourenço, em Direito Tributário pela Fundação Getúlio Vargas, Direito Ambiental e Urbanístico pelo Centro Anhanguera de Promoção e Educação Social e mestre em Direito - linha Constitucionalismo e Democracia - pela Faculdade de Direito do Sul de Minas Gerais. E-MAIL: wagnersflb@gmail.com
\end{abstract}

Recebido em: 13/02/2015 - Aprovado em: 05/06/2015 - Disponibilizado em: 15/07/2015

Resumo: O instituto da usucapião apresenta no Direito pátrio diversas formas, cada qual com suas peculiaridades, sendo certo que, devido a essas características próprias, alguns tipos terão maior aplicabilidade no Direito Agrário e outras permanecerão praticamente inócuas para tal ramo do direito. O presente artigo visa analisar primeiramente, de forma mais ampla, os vários tipos de usucapião correlacionados com o Direito Agrário e posteriormente analisar mais a fundo a usucapião especial rural, que em si demonstra ser a mais agrária das várias espécies desse instituto. Para isso também aborda-se os vários requisitos e dúvidas sobre o instituto, lançando, sempre que possível, soluções plausíveis às indagações ainda em aberto. A metodologia utilizada é método hipotético-dedutivo, por meio de revisão de bibliográfica. Pôde-se então verificar divergências significativas na interpretação da lei e integralizar algumas lacunas.

Palavras-chave: Usucapião, Direito Agrário, Rural, Uso, Visão Geral

\begin{abstract}
The Institute of adverse possession has several forms, each one with its own peculiarities; due to these characteristics, some types have greater applicability in Agricultural Law and other remain virtually without use to this branch of law. This article aims to analyse first; more broadly, the various types of adverse possession correlated with the Agricultural Law and then further analyse the rural special possession, which is the most agrarian of the various species of this institute. For this, also it will be studied the various requirements and doubts about the institute, casting, where appropriate, possible solutions to the questions, which are still, open. The methodology used is the hypothetical-deductive method, through literature review. One could then identify significant differences in the interpretation of the law and solve some gaps.
\end{abstract}

Keywords: Adverse possession, Agricultural Law, Rural, Use, General View 


\section{VISÃO GERAL DA USUCAPIÃO}

Antes que se adentre propriamente no tema, urge que se faça uma passagem, mesmo que de modo resumido, pelos principais pontos relativos à usucapião.

Segundo ensina Diniz (2010, p. 155) usucapião é meio de aquisição da propriedade, mas também pode ser meio de aquisição de outros institutos de direito real, tais como usufruto e servidão.

Para que isso ocorra, deve haver o prolongamento da posse da coisa no tempo; situação essa que ainda deve ser revestida de outras características legalmente estabelecidas (DINIZ, 2010, p. 157).

De fato a distinção entre os vários tipos de usucapião deriva da assimetria entre essas características acessórias e da multiplicidade de períodos legalmente exigidos de posse.

Dessa constatação surge a imperiosa conclusão de que não existe usucapião sem posse; entretanto não se trata de qualquer posse. Muito embora os detalhes possam variar e serem influenciados por cada situação jurídica e/ou fática, podem-se elencar alguns requisitos inerentes à posse capaz de gerar usucapião, são eles: pacificidade, ininterrupção, justiça e o animus domini.

Pode-se dizer que a usucapião deriva em parte do desdém do proprietário para com sua propriedade; nesse sentido a posse do usucapiente não pode ser turbada por terceiros que tenham legítimo interesse na coisa, principalmente o proprietário. Assim a posse deve ter permanecido incólume durante o período temporal exigido pela lei. Por outro lado, se o proprietário perturbar tal posse (DINIZ, 2010, p. 162), seja fisicamente interpelando o possuidor, seja judicialmente, o requisito será perdido, tornando-se a posse sem efeitos para usucapião (DINIZ, 2010, p. 163).

Já o requisito da justiça, na verdade apresenta-se como contraposto à pacificidade, uma vez que entende-se como justa a que não se adquiriu e/ou se mantém por violência ou clandestinidade (DINIZ, 2010, p. 163). Assim se a pacificidade fala de turbações impostas pelo proprietário e/ou terceiros, aqui se fala em ação do próprio possuidor perante terceiros e/ou principalmente contra o proprietário.

Por sua vez o elemento temporal, confere à usucapião sua natureza jurídica de prescrição aquisitiva, apresentando-se de modo diverso à prescrição normal (extintiva), pois se nessa se perde determinado direito pelo decurso temporal, aqui se ganha tal direito (GONÇALVES, 2010, p. 256).

Assim a contagem do tempo é fator inerente e vital para o instituto. Nesse sentido vale a analogia com a vida. Uma vez que a vida seja interrompida não se pode mais restabelecê-la. Do mesmo modo a posse se dá por uma contagem de prazo, sendo certo que sua interrupção gera a perda do período anterior e o reinício desde o começo ( DINIZ, 2010, p. 163).

Assim se um agricultor contava já com três anos de posse de determinada gleba, mas a abandona por determinado período perderá tal período, devendo recomeçar a contagem do tempo para usucapir a terra.

Aqui vale lembrar que tal interrupção pode ser gerada pelo próprio possuidor ou pelo proprietário. Ou ainda pode se dar por ação de terceiro, por caso fortuito ou por força maior.

Nos casos de interrupção por terceiros, por caso fortuito ou por força maior, há de se ponderar que os poderes de gozo do imóvel foram interrompidos por ação alheia à vontade dos interessados, não podendo o possuidor sofrer a perda de anos de trabalho, por exemplo.

Nesse sentido, no Código Civil (CC), reiteradamente vem apresentado o caso fortuito e a força maior como excludentes de situações que fogem do domínio dos interessados. Portanto, o único modo de se compatibilizar a doutrina civilista com a situação aqui tratada seria o entendimento que 
caso o possuidor se visse impedido por uma dessas situações, não estar-se-ia diante de situação de interrupção do prazo.

Ainda no âmbito da ininterrupção, o $\mathrm{CC}$, em instituto claramente social, estabelece que o possuidor pode acrescentar a seu tempo de posse o tempo dos seus ascendentes. É nesse sentido a redação do art. 1.243 do CC.

Quanto a essa possibilidade, deve-se atentar que para que o cômputo seja possível, ambas as posses devem atender aos demais requisitos legais.

Ainda quanto as interrupções de contagem do tempo, pode-se elencar ao lado da classificação anteriormente dada (que se baseia na pessoa), uma outra, apresentada por Opitz e Opitz (2013, p. 104), que separa os casos de interrupção entre naturais e civis, sendo aqueles quando o possuidor abdica da posse ou deixa passar um ano desde eventual esbulho, e esses quando o proprietário aciona o possuidor, quando esse reconhece o direito daquele ou quando se verifica os demais casos de interrupção da usucapião segundo a lei civilista.

Vale ressaltar que o reconhecimento do direito do proprietário ou a ação desse contra o possuidor não necessita ser judicial, mas produz efeito desde que inequívoco(a) (NERY JÚNIOR, 2009, p. 962), valendo para tal inclusive os atos verbais (OPITZ; OPITZ, 2013, p. 105).

Assim, aplicam-se ao instituto todas as causas que impedem, suspendem ou interrompem a prescrição (GONÇALVES, 2010, 257). É o que se pode ler no art. 1.244 do CC.

Assim o leitor deve se dirigir aos arts. 197 a 206 do CC, e lê-los trocando-se as palavras "devedor" por "possuidor" e "credor" por "proprietário" (cartorário).

Finalmente, mas não menos importante tem-se o animus domini.

Diniz (2010, p. 162) esclarece que a intensão de dono é um caráter psicológico que se consubstancia pelo trato diferenciado que o possuidor tem com a coisa.
O caráter egoístico das relações civis impõe ao detentor de coisa que seja ou considere alheia relação de distância, de modo que, principalmente investimentos não serão realizados a menos que sejam indenizados pelo dono ou suposto dono. Por outro lado, o usucapiente tem relação de dono com a coisa, portanto investe seu tempo e seus recursos da mesma forma que investiria se já possuísse o título de domínio. De fato seus atos devem demonstrar que, em sua mente, não há distinção da coisa como de outro, mas sim já integra psicologicamente seu domínio.

Tal caráter é de suma importância, afastando da possibilidade de usucapião o locatário, o comodatário, o usufrutuário, o promitente comprador e assim por diante (DINIZ, 2010, p. 158); todos por não possuírem intensão de dono sobre a coisa, mas sim se relacionarem com ela como pertencente a terceiros.

Mas a Lei civilista ainda exige, adotando a concepção de Ihering, que aos elementos internos, se acrescente o elemento externo de aparência de dono, ou seja, o possuidor para usucapir deve gerar na sociedade a crença de que é ele o proprietário da terra, de modo que todos devem tratá-lo como tal (OPITZ; OPITZ, 2013, p. 103).

Como anteriormente ventilado, ao lado da posse, o tempo é elemento essencial na equação que dá direito a aquisição por usucapião (PEREIRA, 2013, p. 118).

O período varia enormemente de um tipo de usucapião para outro, entretanto ainda assim se pode dizer que sempre guarda o condão de servir como defesa para o proprietário, que pode reaver a coisa caso o decurso temporal não tenha se extinguido, ou para o possuidor que segundo a súmula 237 do STF, pode arguir como defesa a prescrição aquisitiva já consumada.

De mesmo teor é o enunciado 315 da IV Jornada de Direito Civil:

315 - Art. 1.241. O art. 1.241 do Código Civil permite que o possuidor que figurar como réu 
em ação reivindicatória ou possessória formule pedido contraposto e postule ao juiz seja declarada adquirida, mediante usucapião, a propriedade imóvel, valendo a sentença como instrumento para registro imobiliário, ressalvados eventuais interesses de confinantes $\mathrm{e}$ terceiros (BRASIL, 2012).

Também na mesma esteira é o art. $7^{\circ}$ da Lei n ${ }^{0} 6.969 / 81$.

Percebe-se assim que a sentença que reconhecer o direito, independentemente de ser a ação de usucapião ou outra qualquer, servirá como título hábil para registro da propriedade.

Tendo-se em vista que a usucapião é meio de aquisição da propriedade por decurso temporal, uma vez que o usucapiente tenha transcorrido o período aquisitivo com observância de todos os requisitos legais, seu direito encontra-se constituído, ou seja, a sentença judicial somente declarará a propriedade e não a constituirá (OPITZ; OPITZ, 2013, p. 108). Isso conforme o art. 1.241 do CC.

Portanto, após o prazo de aquisição, se o proprietário interpelar o usucapiente, esse poderá, como meio de defesa, utilizar o Poder Judiciário para reconhecer em sentença seu direito sobre o bem; declaração essa que é meio hábil para o registro de sua propriedade.

Referido registro poderá ser feito de forma gratuita caso o possuidor seja hipossuficiente e tenha se valido, durante o processo judicial da assistência judiciária gratuita; isso de acordo com o art. $6^{\circ}$ da Lei ${ }^{\circ}$ 6.969/81.

Entretanto, caso se prove que o possuidor tinha condições financeiras, $\mathbf{o}$ registro somente poderá se dar após o pagamento das custas judiciais. É o que estabelece o parágrafo único do mesmo artigo.

Embora tangentes ao propósito final desse texto, as conjecturas aqui feitas dão subsídio ao leitor para que explore a íntima relação do instituto com o Direito Agrário.

\section{AS DIVERSAS FORMAS DE SE USUCAPIR E O DIREITO AGRÁRIO}

Pereira (2013, p.123 - 134) para classificar as usucapiões em quatro grandes grupos, a saber: usucapião extraordinária, usucapião ordinária, usucapião especial (que o autor subdivide em rural e urbana) e especialíssima;

A essa classificação, pode-se incluir a usucapião indígena (GONÇALVES, 2010, P. 273)

Destas formas pode-se dizer que, para o Direito Agrário, somente não são de relevância direta a usucapião especial urbana e usucapião especialíssima, pois somente aplicáveis a imóveis urbanos.

Por outro lado, deve-se ainda acrescentar à supracitada classificação as usucapiões de coisas móveis descritas nos arts. 1.260 a 1.262 do CC.

Para fins didáticos, como analogia às espécies de usucapião de imóveis e seguindo a nomenclatura de Diniz (2010, p. 177) podese dizer que há dois tipos de usucapião de coisas móveis: uma ordinária e uma extraordinária.

No que se referem à usucapião extraordinária, à usucapião ordinária, à usucapião de coisa móvel extraordinária e à usucapião de coisa móvel ordinária, suas utilizações serão sempre possíveis no âmbito do Direito Agrário, entretanto tratam-se de institutos verdadeiramente civilistas que se aplicam à coisa agrária por conveniência, em um claro diálogo entre os ramos do direito. Diz-se isso, pois os institutos podem ser aplicados tanto para bens urbanos como rurais.

Já no que se refere à usucapião especial rural; o instituto, muito embora codificado no diploma civilista, tem íntima relação com o ramo do Direito Agrário, uma vez que se aplica exclusivamente a imóveis rurais e tem claro cunho social próprio da reforma agrária. Motivo esse pelo qual 
dispensar-se-á análise mais detalhada do mesmo.

Finalmente a usucapião indígena, muito embora sempre ocorra em imóveis rurais, está muito mais afeto aos ramos do Direito Ambiental e de defesa de minorias do que com o Direito Agrário.

\section{AS PRINCIPAIS FORMAS DE SE USUCAPIR NO DIREITO AGRÁRIO}

A primeira forma de se usucapir utilizável do Direito Agrário é a usucapião ordinária.

Apesar de topologicamente no $\mathrm{CC}$ e na maioria da doutrina pátria esse tipo de usucapião ser tratada após a usucapião extraordinária, escolhe-se aqui sua abordagem antecipada, para melhor clareza e entendimento.

$\mathrm{O}$ instituto apresenta todos os elementos anteriormente apresentados no que se refere à posse, acrescendo mais dois requisitos: o justo título e a boa-fé.

No que se refere ao justo título, Diniz (2010, p. 164) descreve ser aquele formalizado, registrado e a princípio capaz de ensejar a transmissão do imóvel, tal como uma escritura ou um formal de partilha, muito embora ele possa ser viciado. Sendo certo que tal falha será apagada pelo decurso temporal que evidencia a convalidação tácita do usucapido.

Com relação ao tempo, o decurso aquisitivo se dará, a princípio, em dez anos.

Entretanto, o CC estabelece que o prazo será reduzido para cinco anos "se o imóvel houver sido adquirido, onerosamente, com base no registro constante do respectivo cartório, cancelada posteriormente, desde que os possuidores nele tiverem estabelecido a sua moradia, ou realizado investimentos de interesse social e econômico" (BRASIL, 2002).

Assim tem-se como condições sine qua non: [1] a aquisição onerosa e, cumulativamente, [2] o registro em cartório competente cancelado a posterior.

No que se refere ao registro cartorário deve-se atentar que o mesmo deve se dar no cartório onde se transmitiria ordinariamente, por compra ou herança, por exemplo, o imóvel. Sendo que se o cancelamento tenha se dado por incompetência do cartório, não se estará diante de tal possibilidade de redução temporal. Isso certamente se dá por segurança jurídica e para que se evite fraudes e clandestinidades.

A essas situações devem necessariamente serem acrescidas de pelo menos uma das seguintes situações alternativas mas cumuláveis: [1] moradia e [2] investimentos de interesse social ou econômico.

A moradia poderá ser habitual ou não; não se podendo entretanto admitir como moradia o pernoite extremamente esporádico.

O legislador se decidiu por escolher expressão genérica ao usar a expressão investimentos.

Tratam-se de quaisquer melhorias que fomente a economia e os fins sociais (função social da propriedade) desde obras necessárias, passando pelas úteis, até ações não edilícias tais como, por exemplo, plantações, principalmente as permanentes de colheitas regulares por se acrescerem ao imóvel e gerarem constantemente trabalho à comunidade.

Diniz (2010, p. 167) chama tal redução de usucapião ordinária abreviada, dando ares de subespécie do instituto usucapião ordinária. Segundo a renomada doutrinadora (2010, p. 167) sua justificativa é o princípio da socialidade, reconhecendo a assim chamada posse-trabalho; o que pode ser lido para fins agrários como um incentivo da execução da função social da propriedade.

Esse tipo de usucapião está codificada no art. 1.242 do CC.

A segunda forma de se usucapir utilizável do Direito Agrário é a usucapião extraordinária. 
O legislador elencou basicamente dois requisitos para que se adquira desse modo a propriedade, são eles: a posse e o tempo. Elementos esses que traduzem, como já visto, o próprio cerne das usucapiões.

No que se refere ao fator temporal, foi estabelecido o prazo matriz de quinze anos; que se justifica por haver inexistência de comprovação de justo título.

Diniz (2010, p. 166) atenta que a presunção juris e de jure de justo título, pois se dispensa sua apresentação.

Quanto a isso a autora (2010, p. 166) alerta que, apesar de haver divergência doutrinária, o CC proíbe que se demonstre a inexistência de tal título.

Muito embora difícil de consecução prática, a lei não proibiu o usucapido de demonstrar a inexistência de justo título, mas sim barrou o juiz de apreciar essa inexistência.

Portanto, pode-se dizer que usucapido poderá apresentar tal situação em juízo, mas ela será em vão. Situação essa que gera procrastinação processual; de onde talvez a ilustre doutrinadora (2010, p. 166) tenha se baseado para tão veemente afirmação.

Também no mesmo diapasão está a questão de boa-fé.

A usucapião extraordinária, por expressa disposição legal dispensa a comprovação de boa-fé.

Surge então a discrição análoga ao justo título anteriormente demonstrada, sendo que faz-se aqui as mesmas ponderações anteriores, inclusive no que toca à presunção juris e de jure feita por Diniz (2010, p. 166).

Retomando-se a questão temporal, o diploma civilista impõe situação no qual o prazo será reduzido para dez anos.

Isso ocorre quando "possuidor houver estabelecido no imóvel a sua moradia habitual, ou nele realizado obras ou serviços de caráter produtivo" (BRASIL, 2002, art. 1.238, parágrafo único).

Há de se entender o que é moradia habitual.
Em contraponto à moradia habitual tem-se a moradia eventual, ou seja, aquela que serve como auxiliar.

Assim moradia habitual será aquela que o indivíduo usa como principal, e, por que não dizer, mantém um vínculo subjetivo mais extremo, sendo ela seu lar.

A outra situação é a execução de obras de caráter produtivo.

De grande relevância é tal possibilidade, uma vez que o Direito Agrário está sempre atento à produtividade da terra, que deve gerar o bem estar da coletividade.

Assim, a implementação de tais obras contribui para que seja dado um fim socialmente correto ao imóvel reestabelecendo ou, pelo menos fomentando, uma função social perdida pelo abandono do proprietário cartorário. $\mathrm{O}$ que, especificadamente no âmbito rural, pode se dar, por exemplo, pela construção de um silo, um terreiro ou mesmo a construção de tanques para criação de peixes e currais para gado. Situações essas que ainda evidenciam o animus domini do proprietário.

Deve-se frisar que as situações descritas no parágrafo único são alternativas mas cumuláveis, ou seja, para fazer jus à redução o usucapiente deve preencher pelo menos uma das duas, porém nada obsta que preencha ambas, sem que isso altere o prazo ou outro atributo.

No que se refere à posse, segundo Diniz (2010, p. 166), ela deve ser: pacífica, ininterrupta, exercida com animus domini.

Esses elementos foram codificados no art. 1.238 do CC.

Ainda na esteira das usucapiões de coisas imóveis que guardam uso no Direito Agrário, vale citar a previsão do art. 1.379 do $\mathrm{CC}$, que estabelece a usucapião de servidões.

De grande valia é tal artigo, pois devido à grande extensão do território rural brasileiro e a distância que as propriedades podem ter de uma via pública, o uso do instituto da servidão é hodierno na vida do homem do campo. 
$\mathrm{O}$ referido artigo remete às necessidades da usucapião ordinária, exigindo portanto que haja justo título e boa-fé, mas ainda reforça a necessidade de que a servidão seja aparente, evitando-se mais uma vez a clandestinidade.

No que se refere à usucapião ordinária se limita ao objeto, sendo que o decurso temporal é idêntico, ou seja, dez anos.

Entretanto o leitor deve se atentar para o que estabelece o parágrafo único do referido artigo, pois o legislador cria um subtipo de usucapião.

Pode-se perceber que o parágrafo único somente altera: [1] o tempo, que passa a ser de vinte anos e [2] dispensa o justo título.

Portanto o parágrafo único não cria situação análoga à usucapião extraordinária, pois o agricultor que deseje usucapir desse modo ainda terá que provar a boa-fé; algo desnecessário na usucapião extraordinária.

Quanto a esse respeito, o STF sumulou entendimento que a execução de obras demonstra que a servidão é aparente (súmula 415).

Ainda no mesmo assunto, a III Jornada de Direito Civil, em seu enunciado 251 , entendeu que o prazo deve ser de quinze anos, no caso do parágrafo único, pois o prazo de vinte anos discrepa do restante do código.

Inspira cautela tal afirmação, já que o prazo é claro e inequívoco, sendo que sua redução por presunção de harmonia pode se assemelhar as atitudes extremadas do ativismo judicial.

Não se deve esquecer que, no caso das servidões, principalmente as rurais, não se está diante de um abandono da área, mas sim em uma benesse concedida de um proprietário a outro.

Ao reduzir tal tempo, não se está corrigindo a falta de um fim social, como nas usucapiões extraordinária ou ordinária, mas somente reduzindo-se um direito de um proprietário que muito provavelmente cumpre sua função. Ou seja, não se corrige nada, mas tão somente reduz-se o direito.
$\mathrm{Na}$ seara das usucapiões de coisas móveis que embora não sejam propriamente de Direito Agrário, mas nele podem ser utilizadas, tem-se a usucapião indígena; isso segundo seu o art. 33.

Embora semelhante à usucapião especial rural, pois somente ocorre sobre área rural, o instituto guarda algumas diferenças.

Primeiramente, apenas pode usucapir indígena, não importando ser ele integrado ou não.

Segundo, o prazo é mais longo; o que se justifica, pois não é necessária a moradia ou o cultivo.

Em terceiro lugar, poder-se-ia apontar a área, mas aqui o leitor deve tomar cuidado, pois se na usucapião especial rural a área é de até cinquenta hectares, aqui ela deve ser menor que cinquenta hectares, ou seja, a área usucapida por usucapião especial rural pode ser maior que a indígena.

Em outra esteira, mas ainda como formas de se usucapir utilizáveis no Direito Agrário, mas não inerentes a ele, têm-se as usucapiões de coisas móveis.

O estudo do tema é restrito, assim como seu tratamento no $\mathrm{CC}$, pois a principal diferença aqui encontrada, não reside nos polos essenciais da usucapião, mas sim na coisa usucapida, que passa de imóvel para móvel.

Desse modo, o art. 1.260 do CC, que define a usucapião ordinária de coisa móvel, se limita a adaptar a matéria do art. 1.242 do $\mathrm{CC}$, somente alterando o tempo para se usucapir, que passa para três anos.

Nessa esteira, o artigo exige justo título e boa-fé.

Já o art. 1.261 do CC, que define a usucapião extraordinária de coisa móvel, muito embora não se assemelhe textualmente do que é dito no art. 1.238 do mesmo CC, tem conteúdo similar, não exigindo boa-fé ou justo título e somente alterando o tempo para se usucapir, que passa para cinco anos.

Finalmente o art. 1.262 do CC solidifica essa dependência das usucapiões de 
coisas imóveis, ao dizer que "[a]plica-se à usucapião das coisas móveis o disposto nos arts. 1.243 e 1.244" (BRASIL, 2002).

A utilidade desses meios de usucapião é a mesma dos ordinário e extraordinário de coisas móveis para o Direito Agrário, ou seja, muito embora não lhe sejam inerentes, sempre poderão ser utilizados.

\section{USUCAPIÃO ESPECIAL RURAL}

A usucapião especial rural, pode ser chamada também de usucapião constitucional, usucapião constitucional rural e usucapião pro labore, entretanto adota-se aqui a nomenclatura 'especial rural', pois conforme salienta Barros (2013, p. 153), tal denominação serve para diferi-la dos meios civis ordinários e, ao mesmo tempo, separa-a do 'especial urbano'.

Trata-se da única usucapião que verdadeiramente sempre se enquadra no objeto de estudo do Direito Agrário, pois somente aplicável em imóveis rurais e seus fins estão plenamente de acordo com os objetivos de tal ramo do Direito.

É justamente esse o primeiro ponto de estudo que deve ser analisado: o imóvel que pode ser usucapido.

O Direito Agrário tende a favorecer o entendimento de que um imóvel é rural se sua destinação assim o for, situação essa defendida, por exemplo, por Marques (2011, p. 100).

Ocorre que aqui a lei civilista consagra outro entendimento, o de zonas urbanas e zonas rurais, próprio de outros ramos do direito como por exemplo o Direito Ambiental.

Portanto, para fins de usucapião especial rural, deve-se entender como imóvel rural, não aquele com destinação rural, mas o que esteja na zona rural do Município de sua situação.

Tal entendimento poderia gerar problemas, já que, por exemplo, uma venda em zona rural seria considerada imóvel rural, teoricamente suscetível ser deste modo usucapida. Entretanto, o leitor deve estar atento, pois a própria letra da lei corrige essa possibilidade, quando dita que serão assim usucapidas as "áreas de terra em zona rural" (BRASIL, 2002, art. 1.239).

Claramente o legislador pôs à mercê deste meio de usucapião uma sorte muito menor de imóveis do que entende o Direito Ambiental ou o Direito Agrário, pois aqui somente fazendas, sítios e similares que concomitantemente estejam na zona rural poderão ser usucapidos.

Assim pode-se dizer que seu objeto será o imóvel em zona rural que tenha destinação rural; excluindo-se assim [1] qualquer imóvel em zona urbana (independentemente de sua destinação ser urbana ou rural) e os imóveis com destinação urbana (independentemente de estarem em zona rural ou em zona urbana).

Ainda nesse assunto a lei limita a área.

Para que se responda tal indagação, urge enfrentar a questão de: qual lei deve ser usada para o presente estudo?

Ocorre que $\mathrm{o}$ art. $1^{\mathrm{o}}$ da Lei $\mathrm{n}^{\mathrm{o}}$ 6.969/81, que "dispõe sobre a aquisição, por usucapião especial, de imóveis rurais" (BRASIL, 1981), estabelece vinte e cinco hectares.

Essa redação, não difere muito do que estabelece o Estatuto da Terra em seu art. 98.

Entretanto o CC, no art. 1.239, fala em cinquenta hectares.

Percebe-se assim que há uma divergência entre os diplomas.

A discussão poderia se aprofundar no que diz respeito a quais das leis prevaleceria, pelos critérios de especificidade ou antiguidade, mas a questão se torna clara ao se recorrer à Constituição da República $(\mathrm{CR} / 88)$, que define cinquenta hectares em seu art. 191.

Encerra-se assim a discussão, pois tanto o art. 98 quanto o art. $1^{\circ}$ da Lei $n^{\circ}$ 6.969/81, não foram recepcionados pela $\mathrm{CR} / 88$; valendo portanto a área ditada pelo 
próprio diploma constitucional e pelo $\mathrm{CC}$, qual seja: igual ou inferior a cinquenta hectares.

Vale ainda dizer que não se trata aqui de impedir a usucapião de imóveis maiores que cinquenta hectares, os quais poderão ser adquiridos pelos meios ordinários supracitados, mas sim de privilégio legal ao possuidor de área nessas condições.

Ressalte-se que uma vez que imóveis agrários são extensões contínuas caracterizadas mais pelo uso do que pela titulação, não é possível restringir a posse de fato de mais de cinquenta hectares pelo simples pedido em ação na qual se requeira a usucapião. Inclusive esse sendo o entendimento da IV Jornada de Direito Civil, a saber:

313 - Arts.1.239 e 1.240. Quando a posse ocorre sobre área superior aos limites legais, não é possível a aquisição pela via da usucapião especial, ainda que o pedido restrinja a dimensão do que se quer usucapir 2012).

Portanto, se a posse for maior que o limite constitucional, o possuidor terá obrigatoriamente que pedir pela usucapião ordinária ou extraordinária, conforme o caso; mas não poderá fazê-lo pelos meios aqui citados.

Registra-se, entretanto, posicionamento contrário, pois Opitz (2013, p. 106) defende ser possível o pedido de usucapião no limite de cinquenta hectares e, posteriormente, o pedido do restante das terras na forma do art. 1.238 do CC.

Percebe-se, entretanto, que a área mínima não foi ditada pelos referidos diplomas.

Quanto a isso deve-se lembrar que, ressalvadas as condições legais explícitas, as quais não se aplicam no presente caso, não se pode possuir no Brasil gleba menor que um módulo rural, pois entende-se que essa seja a menor parcela utilizável para fins agrários.
Portanto, chega-se à conclusão que não se poderá usucapir área menor que um módulo rural por constituir minifúndio, figura combatida no sistema legal agrário pátrio.

Têm-se assim a área mínima de um módulo rural e a máxima de cinquenta hectares.

Ocorre que uma análise sistemática das normas envolvidas conduz a situação de exceção.

O módulo rural varia sensivelmente de região para região do País, podendo chegar a cento e vinte hectares (BARROS, 2013, p. 155). Neste caso estar-se-ia em aparente conflito, pois a propriedade constituída por usucapião especial rural seria imediatamente um minifúndio, ou seja, estaria, teoricamente, impedida de existir.

Porém, como bem salienta o doutrinador (2013, p. 155), por clara imposição constitucional fora instituída exceção, pela qual o minifúndio constituído será plenamente possível e legal.

Também encerrada está a discussão sobre o tempo necessário para se usucapir desse modo, que é de cinco anos. É relevante a esse respeito observar que o cômputo deste tempo se dará observando-se o dia do início da posse e perfazendo-se um ano no mesmo dia e mês do ano calendário seguinte. Repetindo-se tal operação por cinco anos seguidos.

Ao retornar à questão da posse, percebe-se que as tipificações legais atuais evidenciam a necessidade de boa-fé ou de justo título; restando assim a conclusão de que não são parte do instituto, assim como ocorre na usucapião extraordinária (BARROS, 2013, p. 154 - 156). Posição essa corroborada por uma análise histórica feita na Lei $n^{0}$ 6.969/81, que expressamente os dispensava.

Ainda no que se refere à posse, Barros (2013, p. 157) salienta que as demais características da posse, qual sejam pacificidade, ininterrupção, justiça e o animus 
domini, são plenamente aplicáveis ao presente instituto.

Ao voltar de forma tangencial à questão do imóvel, o possuidor deverá transformá-lo em área produtiva. Nesse ponto encaminha-se o leitor aos índices de produtividade contidos na Lei $\mathrm{n}^{0} 8.629 / 93$, que estabelece os índices pelos quais se considera determinada propriedade produtiva ou não.

De fato, a necessidade de produtividade está em total consonância com os ditames jusagrários e, em especial, como demonstra Rodrigues (2010, p. 71), a função social da propriedade, visando o bem estar do cidadão; situações essas que também se veem na obrigação de que essa produtividade se dê por meio do trabalho pessoal ou de sua família, ou seja, o trabalho não pode se dar por meio de prepostos. Requisito esse comumente conhecido por pessoalidade (MARQUES, 2011, p. 99; GONÇALVES, 2010, p. 262).

Essa exigência está contida nos textos civilista e constitucional e em muito se assemelha à propriedade familiar - inclusive, segundo Opitz e Opitz (2013, p. 101) tratando-se de um estímulo legal a tal forma de domínio - e às exigências de um assentamento de reforma agrária, denotando mais uma vez que, apesar da inclusão em texto civilista, o instituto é em essência pertencente ao Direito Agrário, pois carrega consigo seus princípios e exigências.

Vale ressaltar que tal trabalho, à semelhança do que estabelece o art. $4^{\circ}$, inciso II, do Estatuto da Terra, deverá absorver toda a força de trabalho do possuidor e de sua família (OPITZ; OPITZ, 2013, p. 107).

Entretanto, como bem demonstra Barros (2013, p. 155), a norma não especifica em que momento o possuidor tornou-a produtiva, portanto pouco importa se o fez desde o início da posse ou no decorrer dos anos.

Também não há necessidade de que esse trabalho seja ininterrupto. Fato esse também inerente à moradia; que é outro requisito inerente dessa usucapião e fortemente estimulado pelo Direito Agrário.

A moradia, obrigando a fixação do homem no campo e evitando-se o inchaço das cidades pelo êxodo rural; o que, segundo Diniz $(2010,174)$, denota o intuito social do instituto.

Aqui também a lei não estabeleceu quando a moradia deve se iniciar, podendo portanto haver longo período sem o estabelecimento na terra (BARROS, 2013, p. 155).

Trata-se de instrumento que colabora com a reforma agrária, podendo-se incluso aponta-lo como meio para sua execução, pois somente poderá assim usucapir a pessoa que não tiver qualquer outro imóvel, seja urbano ou rural, segundo Opitz (2013, p. 102).

Em que pese a estipulação, Diniz (2010, p. 174 - 175) apresenta divergência doutrinária pela qual alguns autores defendem que, desde que o valor do outro bem seja ínfimo, não se estará diante de impedimento para esse modo de se usucapir.

Em polo oposto está o posicionamento de Barros (2013, p. 155) e Rodrigues (2010, p. 71) que são enfáticos ao frisar que o possuidor do imóvel usucapindo não pode ser proprietário de qualquer outro imóvel.

Corrobora com o entendimento dos doutrinadores supracitados o fato de que, caso tenha tal domínio, ainda sim poderá usucapir pelas formas ordinária ou extraordinária.

Porém, em uma posição mediana que melhor se amolda ao que a lei estabelece e ao que o Direito Agrário visa, não seria possível essa usucapião caso o possuidor exerça domínio sobre outro imóvel, exceto se esse imóvel não fornecesse as condições mínimas de subsistência a ele e sua família.

Assim não se vislumbraria o valor do imóvel (situação menos importante para o Direito Agrário), mas sim se verificaria a capacidade daquele imóvel de fornecer sustento ao possuidor e a sua família (situação que deveras se amolda aos objetivos 
jusagrários). É o caso de agricultor que possua minifúndio, por exemplo.

Outra implicação se refere à propriedade em nome de cônjuge.

Segundo Opitz e Opitz (2013, p. 102), citando Nader, a questão será resolvida conforme o regime de bens que o casal escolhera. Assim: [1] caso o regime seja de comunhão universal, estar-se-ia diante de impedimento; [2] caso o regime seja de comunhão parcial, estar-se-ia diante de impedimento somente caso o bem se comunicasse, ou seja, fosse adquirido posteriormente ao casamento; [3] caso o regime seja de separação, não se estaria diante de impedimento.

Ponto interessante é posto por Barros (2013, 155), que salienta o fato da lei ter dito 'propriedade', que no caso de imóveis se consubstancia pelo registro em cartório. Com isso em vista, o autor (2013, p. 155) defende ser possível o possuidor usucapiente ter posse de outros imóveis, ou seja, não é obste para a lei múltiplas posses, mas tão somente a propriedade.

Ainda no que se refere ao possuidor, a lei, embora não diga expressamente, deixa claro através das expressões - aquele e sua família - que deve ser pessoa natural; posicionamento esse defendido por Gonçalves (2010, p. 262), Marques (2011, p. 99) e Opitz e Opitz (2013, p. 101).

Já Rodrigues (2010, p. 71) revela que não existem impedimentos para a aquisição da propriedade através deste instituto por estrangeiros, sendo que, entretanto, deve-se atentar para o que Opitz e Opitz (2013, p. 113) esclarecem.

Os doutrinadores (2013, p. 114) alertam que a aquisição por usucapião especial rural por estrangeiros sofre restrições, quais sejam, estar legalmente no País e não se enquadrar nas exclusões do art. $3^{\circ}$ da Lei $n^{\circ} 6.969 / 81$.

É de se salientar que não há nada na lei que impeça a usucapião coletiva, sendo possível tal via desde que todos os possuidores perfaçam os ditames legais e sua posse não ultrapasse o montante de cinquenta hectares, caso contrário nenhum poderá usucapir (OPITZ; OPITZ, 2013, p. 110).

No campo das áreas impedidas de serem usucapidas, o principal obste encontrase tipificado no parágrafo único do artigo constitucional não deixa dúvidas de que os imóveis públicos não são passíveis de usucapião.

Nessa baia, Barros (2013, p. 156) assevera a não recepção do art. $2^{\circ}$ da Lei $n^{\circ}$ 6.969/81, que estipulava a (antiga) possibilidade de se usucapir terras devolutas, que são por definição públicas.

Desta disposição, também se abrange grande parte das áreas contidas no art. $3^{\circ}$ da Lei $n^{\circ} 6.969 / 81$.

Tendo-se em vista que a maioria das terras contidas o supracitado artigo já são públicas, e, portanto, insuscetíveis de serem usucapidas, poder-se-ia pensar que o artigo perdera a necessidade; entretanto, embora diminuída, ele ainda se faz necessário, pois os ocupantes dessas áreas ainda fazem jus ao assentamento privilegiado quando de novas declarações.

\section{CONSIDERAÇÕES FINAIS}

Assim, apesar de serem vários os modos de usucapião utilizáveis no campo agrarista, a usucapião especial rural é a única que reúne todas as características de um instituto propriamente desse ramo do Direito.

Como visto, muito embora sua existência não seja nova, ainda residem incertezas, principalmente no campo de sua aplicação, principalmente pela profusão de diplomas sucessivos e, por vezes, lacunosos ou contraditórios, entre si e com o ordenamento agrário.

De modo geral, entretanto, se valendo de métodos hermenêuticos pode-se lançar maior clareza sobre tais pontos.

Com isso demonstrou-se que a usucapião em geral, e principalmente a 
especial rural, representam um importante meio de se fomentar a sustentabilidade no campo através de uma contínua valorização do trabalho na terra.

\section{REFERÊNCIAS}

BARROS, Wellington Pacheco. Curso de Direito Agrário. 8. ed. Porto Alegre: Livraria do Advogado, 2013.

BRASIL. Lei ${ }^{\circ}$ 6.969, de 10 dez. 1981. Dispõe Sobre a Aquisição, Por Usucapião Especial, de Imóveis Rurais, Altera a Redação do $\S 2^{\circ}$ do art. 589 do Código Civil e dá outras providências. Diário Oficial da União, Brasília, 11 dez. 1981. Disponível em: <http://www.planalto.gov.br/ccivil_03/leis/L6 969.htm>. Acesso em: 02 mar. 2015.

BRASIL. Lei $\mathrm{n}^{\mathrm{o}} 10.406,10$ jan. 2002. Institui o Código Civil. Diário Oficial da União, Brasília, 11 jan. 2002. Disponível em: <http://www.planalto.gov.br/ccivil_03/leis/20 02/110406.htm>. Acesso em: 02 mar. 2015.

BRASIL. Jornadas de direito civil I, III, IV e $\mathrm{V}$ : enunciados aprovados / coordenador científico Ministro Ruy Rosado de Aguiar Júnior. - Brasília: Conselho da Justiça Federal, Centro de Estudos Judiciários, 2012

DINIZ, Maria Helena. Curso de direito civil brasileiro. 31. ed. São Paulo: Saraiva, 2014. v. 4.

GONÇALVES, Carlos Roberto. Direito civil brasileiro: direito das coisas. 5. ed. São Paulo: Saraiva, 2010. v. 5.

MARQUES, Benedito Ferreira. Direito agrário brasileiro. 11. ed. São Paulo: Atlas, 2007.
NERY JÚNIOR, Nelson; NERY, Rosa Maria de Andrade. Código Civil comentado. 8. ed. São Paulo: Revista dos Tribunais, 2009.

OPITZ, Silvia C. B.; OPITZ, Osvaldo. Curso completo de Direito agrário. 7. ed. São Paulo: Saraiva, 2013.

PEREIRA, Caio Mario da Silva. Instituições de direito civil. 21. ed. Rio de Janeiro: Forense, 2013. v. 5.

RODRIGUES, Fabrício Gaspar. Direito agrário. Salvador: Juspodivm, 2010. 